\title{
CHINA'S LATEST 'THREAT' TO THE UNITED STATES: THE FAILED CNOOC-UNOCAL MERGER AND ITS IMPLICATIONS FOR EXON- FLORIO AND CFIUS
}

\author{
Joshua W. Casselman*
}

INTRODUCTION

The United States has long encouraged an open investment policy, with nearly every U.S. president since Herbert Hoover taking such a stance. ${ }^{1}$ Yet with an increasingly interdependent and connected world came the need to place limitations on a purely open-door investment policy. ${ }^{2}$ President Reagan exemplifies this necessity in his statement describing the general policy on foreign direct investment in the United States:

The United States seeks to . . f foster a domestic economic climate in the United States which is conducive to investment, ensure that foreign investors receive fair and equitable treatment under our statutes and regulations, and maintain only those safeguards on foreign investment which are necessary to protect our security and related interests. ${ }^{3}$

The Exon-Florio provision of the Defense Production Act of 1950 currently embodies this important limitation to the United States' free trade and investment stance. ${ }^{4}$ Exon-Florio authorizes the President or his designee to investigate a proposed or completed foreign acquisition and the President to prohibit such an acquisition if he determines that it poses a threat to national security. ${ }^{5}$

Since its implementation, Exon-Florio has been the source of considerable criticism, and numerous proposals for amendment have been suggested. ${ }^{6}$ Recently, proposals for change in Exon-Florio have been spurred

\footnotetext{
* J.D. candidate, May 2007. B.A. Albion College 2004. The author would like to express his appreciation to Prof. Antony Page for his assistance with this Note.

1. Jacqueline J. Ferber, Comment, The U.S. Foreign Direct Investment Policy: The Quest for Uniformity, 76 MARQ. L. REV. 805, 810 (1993).

2. See generally id. (discussing U.S. Foreign Investment Policy in the 1990 s especially with regard to increased Japanese investment in the United States).

3. Statement of the President Transmitting International Investment Policy, 19 WKLY. COMP. PRES. DOC. 1214, 1216-17 (Sept. 9, 1983).

4. 50 U.S.C. $\S 2170$ (2005).

5. Id.

6. See ON THE IMPLEMENTATION OF THE EXON-FLORIO AMENDMENT AND THE COMMTTEE ON FOREIGN INVESTMENT IN THE UNITED STATES: BEFORE THE SENATE COMMITTEE ON BANKING,
} 
by China National Offshore Oil Corporation's (CNOOC) high-profile bid for American-based Unocal Corporation, a producer of oil and natural gas. ${ }^{7}$ As will be discussed below, Congress used national security arguments and antiChina rhetoric to justify close scrutiny of the deal, which resulted in the passage of several resolutions and bills. ${ }^{8}$ Congress successfully politicized CNOOC's offer to buy Unocal by turning the bid into a showdown between the United States and China for economic and military power, with any gains by China viewed as losses to the United States. ${ }^{9}$ Ultimately, Congress exerted sufficient pressure on CNOOC that it withdrew its bid. ${ }^{10}$

In the wake of CNOOC's failed bid, the United States' policy on foreign direct investment is unclear. Protectionist-minded members of Congress are raising concerns that Exon-Florio and the Committee on Foreign Investment in the United States (CFIUS), which was delegated the authority to carry out Exon-Florio's requirements, are not adequately protecting national security and should be strengthened. ${ }^{11}$ Proposed changes have called for increased congressional authority to regulate foreign investment and for significant procedural and substantive alterations to be made in Exon-Florio and CFIUS. ${ }^{12}$ Whether these proposals are actually warranted or merely the product of an increasing anti-China trend are important issues, as any change in current foreign investment policy could have significant economic implications in the United States. $^{13}$

This Note examines current proposals for amending Exon-Florio and altering the structure of CFIUS. It argues that some minor changes to ExonFlorio are warranted, but that it is currently unnecessary to drastically alter its statutory framework or the structure of CFIUS. Part I of this Note provides an overview of Exon-Florio itself and discusses how the statute has been applied to foreign acquisitions. Part II provides an overview of the failed CNOOCUnocal merger and argues that congressional outcry over CNOOC's bid was unwarranted and unwise. Part III examines the Government Accountability Office's (GAO) recent report on the effectiveness of Exon-Florio, its recommendations for change, and the response by some CFIUS agencies to the

HousING AND URBAN AFFAIRS, 109th Cong. (2005) (statement of David Marchick, Partner, Covington \& Burling), for a discussion of the potentially negative impacts of implementing recent proposals to amend Exon-Florio.

7. Christopher Corr, Pressures to Stiffen Exon-Florio: The Chinese Bid for Unocal Sparks a Firefight Over Inbound Deals, MERGERS \& ACQUISITIONS, Jan. 1, 2006, at 34-38.

8. James A. Dom, Policy Analysis: U.S.-China Relations in the Wake of CNOOC, POL'Y ANALYSIS, Nov. 2, 2005, at 6.

9. Id.

10. David Barboza \& Andrew Ross Sorkin, Chinese Company Drops Bid to Buy U.S. Oil Concern, N.Y. TIMES, Aug. 3, 2005, at A1.

11. Corr, supra note 7.

12. See U.S. Gov't ACCOUNTABILITy Office, Defense Trade: Enhancements to THE IMPLEMENTATION OF EXON-FLORIO COULD STRENGTHEN THE LAW'S EFFECTIVENESS (2005) [hereinafter GAO]; see also S. 1797, 109th Cong (2005).

13. See Marchick, supra note 6, at 3-4, for a brief discussion of the importance of foreign investment to the U.S. economy. 
report. It also introduces the most recent legislative proposals to amend ExonFlorio and alter CFIUS. Part IV provides a critical review of the GAO report recommendations and current legislative proposals and offers suggestions to improve Exon-Florio based in part upon lessons learned from the failed CNOOC-Unocal transaction and other general considerations.

\section{THE EXON-FLORIO ACT}

\section{A. Purpose, Requirements, and Structure}

Prior to the adoption of the Exon-Florio provision, many in Congress believed that foreign acquisition of U.S. firms could be stopped only if the President declared a national emergency. ${ }^{14}$ The President hesitated to take such a drastic measure because doing so was essentially "a declaration of hostilities against the government of the acquirer company," an action considered politically dangerous. ${ }^{15}$ Particularly concerned with Japanese acquisitions of certain types of U.S. firms and believing it was powerless to take any action, Congress approved the Exon-Florio provision of the Defense Production Act in 1988. ${ }^{16}$

Exon-Florio authorizes the President to take "appropriate" action "to suspend or prohibit foreign acquisitions, mergers, or takeovers of U.S. businesses" determined to threaten the national security of the United States. ${ }^{17}$ The meaning of "national security," however, is not defined in the Exon-Florio provision, with Congress intentionally leaving the term undefined so that it could be "interpreted broadly without limitation to a particular industry.",18 Exon-Florio limits the President's authority to prohibit or suspend foreign acquisitions by requiring that he first find "credible evidence" that the foreign acquisition will impair national security and that no other provisions of law are adequate or appropriate to protect national security. ${ }^{19}$

By Executive Order 12,661, the President delegated his authority under

14. James K. Jackson, The Exon-Florio National Security Test for Foreign INVESTMENT 2 (2005).

15. Christopher R. Fenton, Note, U.S. Policy Towards Foreign Direct Investment PostSeptember 11: Exon-Florio in the Age of Transnational Security, 41 COLUM. J. TRANSNAT'LL. 195,203 (2002).

16. JACKSON, supra note 14, at 2.

17. Id. See also 50 U.S.C. app. $\$ 2170(2005)$.

[T] appropriate to suspend or prohibit any acquisition, merger, or takeover, of a person engaged in interstate commerce in the United States proposed or pending. . by or with foreign persons so that such control will not threaten to impair the national security.

Id.

18. JACKSON, supra note 14 , at 2 .

19. Id. 
Exon-Florio to CFIUS. ${ }^{20}$ CFIUS is housed in and chaired by the Department of the Treasury and consists of twelve members. ${ }^{21}$ The twelve-member panel includes:

the Secretaries of State, Treasury, Defense, Homeland Security, and Commerce; the United States Trade Representative; the Chairman of the Council of Economic Advisors; the Attorney General; the Director of the Office of Management and Budget; the Director of the Office of Science and Technology Policy; the Assistant to the President for National Security Affairs; and the Assistant to the President for Economic Policy. ${ }^{22}$

The CFIUS panel is overseen by the Senate Banking, Housing and Urban Affairs Committee, which is currently chaired by Alabama Senator Richard Shelby, one of the strongest proponents of reform in Exon-Florio and CFIUS. ${ }^{23}$

Exon-Florio lists a number of factors that CFIUS may consider in determining what constitutes a threat to "national security." These factors include: "domestic production needed for projected national defense requirements"; whether domestic industries have the capability and capacity to meet national defense requirements, which include such things as human resources, technology, and materials; "the potential effects of the transactions on the sales of military goods, equipment, or technology to a country that supports terrorism or proliferates missile technology or chemical or biological weapons"; and "the potential effects of the transaction on U.S. technological leadership in areas affecting U.S. national security."24

After receiving written notification of a proposed merger, acquisition, or takeover, CFIUS has thirty days to review potential national security threats of a transaction and determine if a full investigation is warranted. ${ }^{25}$ If CFIUS chooses to further investigate after this thirty-day period, it then has an additional forty-five days to complete its full investigation and provide a recommendation to the President. ${ }^{26}$ Ultimate authority to decide whether a

20. Id. at 3 .

21. $I d$.

22. Id.

23. See Stephanie Kirchgaessner, Senate Unease at Vetting Procedure, FN. TMEs, Oct. 7, 2005 (statement of Sen. Richard Shelby) ("The Treasury Department may believe that the process is sufficiently transparent ... . This is the United States Senate committee with jurisdiction over the process question, and we most certainly do not agree.").

24. JACKSON, supra note 14 , at 3 . See 50 U.S.C. app. $\$ 2170$ (f) (2005), for a full list of factors that may be considered.

25. See 50 U.S.C. app. $\$ 2170$ (a) (2005) ("“An] investigation shall commence not later than 30 days after receipt by the President or the President's designee of written notification of the proposed or pending merger, acquisition, or takeover ....").

26. See 50 U.S.C. app. $\$ 2170$ (2005) ("Such investigation . . . shall be completed not later than 45 days after its commencement."). 
proposed foreign acquisition should be prohibited is given to the President, who is required to make his final decision within fifteen days after the CFIUS investigation is complete. ${ }^{27}$ The President must send a written report of his decision to Congress, which includes an explanation of his findings and the factors listed under the Exon-Florio provision that were considered in reaching his decision. ${ }^{28}$ In total, CFIUS's review process cannot exceed ninety days. ${ }^{29}$

Foreign parties are not required to voluntarily submit notification of a proposed acquisition to CFIUS. ${ }^{30}$ However, they have an incentive to do so because Exon-Florio authorizes the President to order companies to divest completed acquisitions that threaten the national security where they fail to notify CFIUS of the acquisition. ${ }^{31}$ In addition, where parties fail to voluntarily notify CFIUS of a transaction, any CFIUS agency can authorize a review of a transaction of which it becomes aware. ${ }^{32}$ Foreign companies that have filed with CFIUS can request to withdraw their notification at any time during CFIUS's review process, as long as withdrawal occurs before the President announces his decision on the matter. ${ }^{33}$ Withdrawing companies can then refile at a later date where it is considered a new, voluntary notice to CFIUS and the thirty day review process begins again. ${ }^{34}$

The U.S. Department of Treasury states that the Exon-Florio provision is implemented within the context of the traditional U.S. open investment policy. ${ }^{35}$ This policy is said to welcome foreign direct investment and afford "foreign investors fair, equitable, and nondiscriminatory treatment with exceptions" made only to protect national security. ${ }^{36}$

\section{B. Applying Exon-Florio}

"CFIUS has received more than 1500 notifications" since the enactment of Exon-Florio and has chosen to proceed past the thirty day review period in approximately twenty-five cases. ${ }^{37}$ Of these twenty-five cases that were to proceed to the full investigation stage, thirteen were withdrawn by the foreign acquirer upon notice that CFIUS would conduct a full investigation, while the

27. Id.

28. Id.

29. U.S. Dep't Treasury, Committee on Foreign Investments in the United States (CFIUS), http://www.treas.gov/offices/international-affairs/exon-florio/ (last visited Dec. 12, 2006).

30. GAO, supra note 12 , at 8 .

31. Id. at 9.

32. Letter from Linda L. Robertson, Assistant Secretary of the Dep't of Treasury, to John Warner, Chairman of the Comm. on Armed Serv. (Jul. 23, 1999) (on file with author).

33. GAO, supra note 12 , at 10.

34. Id.

35. U.S. Dep't. Treasury, supra note 29.

36. Id.

37. JACKSON, supra note 14, at 4 . 
remaining twelve transactions were sent to the President for his decision. ${ }^{38}$ More specifically, in 2004 CFIUS received notification of forty-five transactions that underwent a thirty day review period, but initiated only one full investigation that required a report and recommendation for the President's decision. ${ }^{39}$ Since the enactment of Exon-Florio, the President has blocked only one of the twelve transactions in which CFIUS has conducted a full seventyfive day investigation. ${ }^{40}$

The small number of full forty-five day investigations undertaken by CFIUS has been the source of considerable criticism. ${ }^{41}$ Some have argued that CFIUS's reluctance to initiate investigations results from "the negative connotations of an investigation and the need for a presidential decision." 42 For example, public knowledge of an investigation may have the effect of reducing investor confidence, which in turn could cause the company's stock prices to fall. $^{43}$ The Treasury Department has stated that CFIUS's decision whether to initiate an investigation demands careful deliberation because a forty-five day investigation potentially requires the President to make a decision about the foreign acquisition. ${ }^{44}$ The Treasury Department believes CFIUS investigates the appropriate number of cases, stating that Congress intentionally "limited Exon-Florio to situations where other tools were not adequate or appropriate to deal with a national security threat."45

As demonstrated by the figures above, the practical effect of Exon-Florio is that foreign entities have voluntarily withdrawn bids to avoid a full CFIUS investigation much more frequently than they have been prohibited from acquiring U.S. companies. But the existence of CFIUS plays a role beyond the occasional deterrent effect of its investigation process; it can also persuade

38. Id.

39. Dep't of Treasury, Part II - Annual Performance Report: Fy 2004 PERFORMANCE AND ACCOUNTABILITY REPORT 47 (2004), available at http://www.treas.gov/offices/management/dcfo/accountability-reports/2004reports/part2.pdf.

40. JACKSON, supra note 14, at 4. The prohibited transaction took place in 1990 when China Aero-Technology Import and Export Corporation (CATIC) sought to acquire U.S.-based Mamco Manufacturing Company, an aerospace parts manufacturer. Id. The People's Republic of China owns CATIC and was acting as purchasing agent for the Chinese Ministry of Defense in the deal. Id. Using his power under Exon-Florio, President Reagan ordered CATIC to divest itself of Mamco, citing concerns that CATIC would gain access to technology that could otherwise have been acquired only through an export license. Id.

41. See GAO, supra note 12, for a critical analysis of CFIUS.

42. Id. at 13.

43. Id. at 14. A CFIUS investigation could adversely affect stock prices because the prospect of an investigation makes a merger less likely.

44. Id. at 31.

45. Id. at 28. More specific laws that protect the national security include those that restrict foreign ownership of U.S. air carriers, restrict the export of sensitive technology, and restrict access to sensitive information. Id. In addition, even if the Unocal board had approved the CNOOC bid, it would have been "subject to regulatory review for possible anticompetitive effects." Laura D'Andrea Tyson, What CNOOC Leaves Behind; Existing Mechanisms Can Assess Risks to U.S. National Security, Bus. WK., Aug. 15, 2005, at 101. 
foreign entities to restructure the terms of the acquisition in ways that address CFIUS's security concerns. ${ }^{46}$ As an example, in 2000 CFIUS allowed the Japanese Nippon Telephone \& Telegraph Company to acquire the U.S.-based Internet service provider Verio after the Japanese government agreed to a strict ban on any involvement in the firm. ${ }^{47}$ In addition, an otherwise highly critical GAO report found that CFIUS has recently made substantial improvements in obtaining and enforcing mitigation measures under Exon-Florio. ${ }^{48}$

The Department of Homeland Security has taken the lead role in monitoring compliance for these agreements, and such agreements have recently included more specific time frames for compliance and stronger language concerning noncompliance with contractual terms. ${ }^{49}$ Likewise, as will be discussed more fully, CNOOC's apparent willingness to fully cooperate with the CFIUS review process and its assurances to sell Unocal's domestic assets exclusively to the United States may provide further indications of the benefits of CFIUS's deal-restructuring role.

\section{CNOOC'S BID FOR UNOCAL}

\section{A. Explaining What Happened}

To fuel its booming economy, ${ }^{50}$ China has developed a voracious appetite for new and improved energy supplies. In fact, according to the U.S. Department of Energy, China surpassed Japan in 2003 to become the world's second largest oil consumer after the United States. ${ }^{51}$ Given China's relative infancy in the world oil market, however, it lacks the established historical oil supply links necessary to meet its demands. ${ }^{52}$ This has led China into ventures, such as that of CNOOC's offer to purchase Unocal, which seek to establish supply arrangements for new oil reserves to China. ${ }^{53}$

What has been described as "one of the of the most politically charged merger battles in U.S. history" " began on June 23, 2005, when CNOOC made

46. James A. Lewis, New Objectives for CFIUS: Foreign Ownership, Critical Infrastructure, and Communications Interception, 57 FED. COMM. L.J. 457, 465 (2005).

47. JACKSON, supra note 14 , at 5 .

48. GAO, supra note 12 , at 18.

49. Id. at 18-19.

50. Wayne M. Morrison, CHINA's Economic CondrTIONS, CRS Issue Brief for Congress, at 2 (2005), http://www.fas.org/sgp/crs/row/IB98014.pdf. China's real gross domestic product (GDP) has grown an average annual rate of $9.3 \%$ from 1979 to 2004 . Id. In the first quarter of 2005, real GDP grew by approximately $9.4 \%$. Id.

51. Dick K. NANTo et al., ChINA AND the CNOOC Bid fOR UNOCAL: Issues fOR CONGRESS 3 (2005).

52. Id. As noted later, China has a preference for captive supply sources, infra note 105.

53. Id.

54. Christopher Palmeri, Unocal Goes Out With a Bang, Bus. WK. ONLINE, Aug. 11, 2005, http://www.businessweek.com/bwdaily/dnflash/aug2005/nf20050811_8247_db017.htm. 
an unsolicited $\$ 18.5$ billion cash offer to purchase the California-based energy company Unocal. ${ }^{55}$ The bid sparked great controversy in Washington, D.C., for a number of reasons. To begin, CNOOC is no ordinary energy company. It is China's third largest oil group, its largest offshore oil and gas producer, ${ }^{56}$ and, most importantly, it is $70 \%$ owned by a state-controlled company. ${ }^{57}$ The merger with Unocal would have more than doubled CNOOC's oil and gas production and increased its reserves by nearly $80 \% .{ }^{58}$ In addition, CNOOC's offer was to be heavily subsidized by state-owned companies and banks. ${ }^{59}$ CNOOC's parent company, China National Offshore Oil, agreed to subsidize $\$ 7$ billion of the offer, $\$ 2.5$ billion of which was interest free and the rest a thirty-year loan at $3 \%$ interest. $^{60}$ A state-owned bank agreed to loan CNOOC another $\$ 6$ billion. ${ }^{61}$ These generous loans led many in Washington to view CNOOC's offer as an effort by the Chinese government to overtake a private American oil company, rather than a pure commercial transaction. ${ }^{62}$ Fueling the controversy was the fact that CNOOC's bid came only two months after Chevron Corporation, the United States' fourth-largest oil company, had agreed to acquire Unocal for $\$ 16.4$ billion in cash and stock. ${ }^{63}$

In an effort to ease U.S. concerns over the offer, CNOOC provided a number of terms favorable to U.S. interests in its proposal. CNOOC expressed its willingness "to continue Unocal's practice of selling and marketing all or substantially all of the oil and gas produced from Unocal's U.S. properties in U.S. markets." 64 CNOOC further promised to retain substantially all Unocal employees, including those in the United States. ${ }^{65}$ This position stood in contrast to the existing Chevron proposal, in which Chevron had "announced plans to extract hundreds of millions of dollars of cost savings from the merger annually," which likely would have included employee layoffs. ${ }^{66}$ Further, CNOOC's offer provided that it would attempt "to persuade members of

55. NANTO ET AL., supra note 51 , at 1.

56. Asia Times Online, CNOOC Bids US\$67 Per Share for Unocal, June 24, 2005, http://atimes.com/atimes/China/GF24Ad01.html.

57. NANTO ET AL., supra note 51, at 7.

58. Press Release, CNOOC Ltd., CNOOC Limited Proposes Merger with Unocal Offering US\$67 Per Unocal Share in Cash (June 23, 2005) [hereinafter Press Release], http://www.cnoocltd.com/press/channel/press1612.asp.

59. National Security Dimensions of the Possible Acquisition of Unocal by CNOOC and the Role of CFIUS: Before the House Committee on Armed Services (July 13, 2005) (statement of Hon. C. Richard D'Amato, Chairman, U.S.-China Economic and Security Review Commission), available http://www.uscc.gov/testimonies_speeches/testimonies/2005/05_07_13_testi_damato.htm.

60. Id.

61. Id.

62. Id.

63. Cathy Landry, Congress Lashes Out on Cnooc Bid For Unocal; Chevron Stands By Its Competing \$16.4-Bil Offer, PlatTs OilgRam Price RePORT, June 24, 2005, at 1.

64. Press Release, supra note 58.

65. Id.

66. Id. 
Unocal's executive and operational management to join the management team of the combined company." ${ }^{, 67}$ Lastly, CNOOC voluntarily filed notification to CFIUS of the proposed transaction, claiming that it was willing to fully discuss its proposal and participate in the CFIUS review process to demonstrate that its motives behind the transaction were purely commercial. ${ }^{68}$

Even with CNOOC's assurances, the offer was greeted by a wave of criticism in Washington, D.C. ${ }^{69}$ Just one week after CNOOC's bid was announced, Congress made clear its reservations about the proposed merger through legislation intended to thwart or, at least, delay the transaction. On June 30, 2005, the House of Representatives overwhelmingly passed House Resolution 344, proposed by Representative Richard Pombo of California, by a vote of 398 to $15 .^{70}$ The resolution expressed the House's belief that CNOOC, through its control of Unocal, could take action that would impair the national security of the United States and called for the President to initiate an immediate review of the proposed acquisition if Unocal entered into the agreement. $^{71}$ That same day, the House cut off funding to CFIUS by passing House Amendment 431, which prohibited the Treasury Department from spending any money to approve the sale of Unocal to CNOOC. ${ }^{72}$

On July 15, 2005, Senator Byron Dorgan proposed a joint resolution to prohibit the acquisition of Unocal by CNOOC. ${ }^{73}$ This proposal was based in part on several of the general concerns noted above: oil and natural gas are strategic assets critical to national security; the Chinese government owns $70 \%$ of CNOOC's parent company; a significant portion of the acquisition would be financed by banks owned by the Chinese government; the strategic assets of Unocal would be preferentially allocated to China by the Chinese government; and, under Chinese law, the U.S. Government and U.S. investors would not be allowed to acquire a controlling interest in a Chinese energy company. ${ }^{74}$

On August 8, 2005, House Resolution 6/P.L. 109-58 energy bill was signed into law. ${ }^{75}$ The bill included a provision requiring a four-month long study by the Secretaries of Defense and Homeland Security on China's energy needs and the political, strategic, economic, and national security implications of China's growing energy requirements before the CNOOC bid could be approved. $^{76}$ A legislator responsible for the proposal admitted that the measure

67. Id.

68. Wang Ying, CNOOC Volunteers for Acquisition Review, CHINA DAILY, July 4, 2005, available at http://www.chinadaily.com.cn/english/doc/2005-07/04/content_456838.htm.

69. NANTO ET AL., supra note 51, at 1.

70. H.R. Con. Res. 344, 109th Cong. (2005) (enacted).

71. Id.

72. H.R. Con. amend. 431, 109th Cong. (2005) (enacted).

73. S. 1412, 109th Cong. (2005).

74. Id.

75. NANTO ET AL., supra note 51, at 15 .

76. Id. 
was specifically intended to stall the CNOOC-Unocal merger. ${ }^{77}$

While congressional outcry over CNOOC's bid created public awareness of the potential implications of the acquisition and put political pressure on CNOOC to withdraw its offer, President George W. Bush remained virtually silent on the proposed bid. ${ }^{78}$ The following statement made on July 17, 2005 by President Bush fairly states his position throughout the CNOOC-Unocal ordeal: "There is a process that our government uses to analyze such purchases or intent to purchase. And it's best that I allow that process to move forward without comment."79

On August 2, 2005, exactly one month after it filed notice with CFIUS, CNOOC withdrew its bid, citing mounting opposition in Washington, D.C. ${ }^{80} \mathrm{~A}$ spokesperson for CNOOC stated that the political environment had made it very difficult for the company to assess its chance of success, which created "a level of uncertainty that presented an unacceptable risk to" its ability to secure the transaction. ${ }^{81}$ Shortly after CNOOC's withdrawal, over 77\% of Unocal's shareholders approved the sale of the company to Chevron, who had previously increased its bid to $\$ 17$ billion. $^{82}$ Ironically, due to unprecedented congressional opposition to the bid, CFIUS - the committee actually delegated the authority to investigate the national security risks of foreign acquisitionnever got the chance to fully perform its responsibilities.

\section{B. Was Congress' Reaction to CNOOC's Bid Warranted?}

CNOOC's attempted acquisition of Unocal appears to have lit or at least rekindled a protectionist-fueled fire in many lawmakers. As will be discussed below, the failed merger has led to the proposal of amendments that would alter the definition of "national security" under Exon-Florio, increase congressional authority to prohibit certain types of foreign investment, and alter the structure of CFIUS. Therefore, it is useful to examine whether congressional outcry over CNOOC's bid was justified in the first place. The answer to this question may provide insight as to whether it is truly in our nation's best interest to have Congress increase its discretion and control over foreign investment and may provide indications as to whether CFIUS and Exon-Florio need to be overhauled.

The bulk of Unocal's assets consist of oil and gas operations in eight

77. Jad Mouawad, Congress Calls for a Review of the Chinese Bid for Unocal, N.Y. TIMES, July 27, 2005, at 3.

78. NANTO ET AL., supra note 51, at 14.

79. Todd Bullock \& Katie Xiao, Bush Administration Says Review of Chinese Unocal Bid Premature (July 19, 2005), http://usinfo.state.gov/eap/Archive/2005/Jul/19-919521.html.

80. NANTO ET AL., supra note 51, at 14.

81. Id.

82. Unocal Shareholders Approve Chevron Offer, USA TODAY, Aug. 25, 2005, http://www.usatoday.com/money/industries/energy/2005-08-10-unocal-chevronapproval_x.htm. 
countries outside North America, including: Thailand, Indonesia, Bangladesh, Myanmar, the Netherlands, Azerbaijan, Congo, and Brazil. ${ }^{83}$ Its North American operations primarily take place in the Gulf of Mexico, Canada, and Alaska. ${ }^{84}$ Even with its expansive operations, Unocal is only the United States' ninth-largest oil company ${ }^{85}$ and does not rank among the top forty global oil or gas firms. ${ }^{86}$ Its 2004 gross revenue figures of $\$ 8.2$ billion are comparable to that of large independent energy producers and pale in comparison to the gross revenues of major multinational oil companies. ${ }^{87}$ In addition, $70 \%$ of Unocal's proved oil and gas reserves are in Asia and the Caspian Region, ${ }^{88}$ and it does not import crude oil into the United States because it owns no refineries. ${ }^{89}$ Further, Unocal's domestic oil production of 58,000 barrels per day translates into less than $1 \%$ of total domestic production. ${ }^{90}$

In short, Unocal is a relatively minor player on the world's oil and gas scene, ${ }^{91}$ which draws into question whether Unocal can fairly be deemed a "strategic asset" of the United States. Had the CNOOC-Unocal merger been completed, "combined CNOOC-Unocal's natural gas production would have amounted to about $1 \%$ of U.S. consumption, and combined oil production would have been equivalent to about $0.3 \%$ of domestic U.S. consumption."92

Admittedly, these facts focus on this specific transaction only and do not take into account the aggregate effects that multiple transactions involving Unocal-size companies might have on national security. ${ }^{93}$ The potential aggregate affect was a concern of some politicians, including Representative Tom Tancredo, who stated: "By itself, this takeover may seem small, but a few more deals like this one and America could find itself held hostage not just to the energy brokers in the Middle East but to China as well."94 Nevertheless, CFIUS is arguably "well equipped to make national security assessments of Chinese investment in the United States on a case-by-case basis," which should

83. NANTO ET AL., supra note 51 , at 10.

84. Id.

85. ChevronTexaco's Plan to Buy Unocal Reverses Driller's Outlook, ALEXANDER's GAS \& OIl CONnEctions; COMPANy News: N. AM., Apr. 20, 2005, available at www.gasandoil.com/goc/company/cnn51636.htm.

86. The Dragon Tucks In, ECONOMIST, June 30, 2005, available at http://www.economist.com/business/globalexecutive/dialogue/displayStory.cfm?Story_id=4127 399.

87. NANTO ET AL., supra note 51 , at 9.

88. Press Release, supra note 58.

89. NANTO ET AL., supra note 51, at 11.

90. Jerry Taylor, CNOOC Bid for Unocal No Threat to Energy Security, FREE TRADE BuLl., July 19, 2005, available at www.freetrade.org/pubs/FTBs/FTB-019.pdf.

91. The Dragon Tucks In, supra note 86.

92. NANTO ET AL., supra note 51, at 11.

93. Cf. Mark E. Rosen, Restrictions on Foreign Direct Investment in U.S. Defense and High Technology Firms: Who's Minding the Store?, 4 U.S.A.F. ACAD. J. LEGAL STUD. 75, 81 (1993).

94. Dorn, supra note 8, at 5. 
alleviate most of these cumulative effect concerns. ${ }^{95}$

In addition to Unocal's valuable oil assets, concerns were raised that Unocal also possessed dual-use technology that would find its way into the hands of the Chinese government if the bid was consummated. ${ }^{96}$ Specifically, some believed Unocal possessed sensitive technology used for its deep sea exploration and drilling that could prove to benefit the Chinese military. ${ }^{97}$ Still others believed that Unocal did not possess any technology in its oil sector that was not available to China through contractors or private vendors. ${ }^{98}$ Regardless which of these positions is accurate, CFIUS would almost certainly have considered Unocal's possession of dual-use technology under a factor of ExonFlorio, which allows CFIUS to consider the effects of a transaction on United States technological leadership in areas affecting national security, in evaluating potential threats to national security. ${ }^{99}$ Of course, because of congressional reaction to CNOOC's bid, CFIUS was never afforded that opportunity.

Some members of Congress believed that CNOOC's all cash bid, which trumped that of Chevron's cash and stock offer, was the result of CNOOC's unfair market advantage. ${ }^{100}$ Since CNOOC is $70 \%$ state-owned and its offer was heavily subsidized by state-owned banks and companies, some in Washington scoffed at CNOOC's claim that its offer was mere normal commercial activity. ${ }^{101}$ Still, contrary to what some in Washington believed, CNOOC may have actually overbid for Unocal rather than unfairly circumvented the market. As Gary Becker, a professor of economics at the University of Chicago explained:

[M]ost large state-owned enterprises in China are inefficiently run, and they can only receive loans from state banks because banks are politically forced to make these loans. As a result, bank loans to state enterprises amounting to hundreds of billions of dollars are in trouble, and many are considered worthless. So it is very likely that CNOOC overbid for the assets of Unocal, which would have meant a transfer of dollars to stockholders of Unocal from the Chinese government. ${ }^{102}$

In addition, U.S. oil companies have also benefited from government assistance and thereby gained an advantage over other foreign countries by way

95. Marchick, supra note 6 , at 7 .

96. D'Amato, supra note 59.

97. Id.

98. Dorn, supra note 8 , at 5 .

99. See 50 U.S.C.S. app. § 2170 (2005).

100. Landry, supra note 63 , at 1.

101. D'Amato, supra note 59.

102. Posting of Gary Becker to The Becker-Posner Blog, Chinese Ownership of American 
of an energy bill that provides them with tax breaks. ${ }^{103}$ Regardless, CNOOC's advantages from low-interest loans should not be overstated; Chevron also may have been able to obtain financing internationally at favorable market rates that are low in relation to historic standards. ${ }^{104}$ CNOOC's willingness to pay a premium for Unocal may have had much more to do with its preference for captive supply sources than the desire to gain unfair economic advantage by avoiding the purely private market. ${ }^{105}$

Some members of Congress viewed CNOOC's offer as a threat to the United States' ability to obtain oil and gas for its own economy, citing concerns that China could lock up energy supplies around the world for its own use. ${ }^{106}$ Given the fungible nature of oil, however, most oil experts are not concerned about such a problem. ${ }^{107}$ Experts point to the vast and fluid nature of oil markets and note that tankers full of crude oil are readily swapped between traders to balance excess demand or supply in areas throughout the globe. ${ }^{108}$ Put simply, CNOOC's purchase of Unocal's oil assets would have offset purchases it would have had to make elsewhere, which in turn would have made that oil available for purchase by the United States. ${ }^{109}$ Further, oil experts say that China's increased ownership of oil reserves would not change the price of oil because the hoarding of oil for its own use would have come at the cost of missing out on the opportunity to sell that oil on the open market at a higher price. ${ }^{10}$ Gary Becker explains oil as a fungible commodity in this way:

The US already imports about $2 / 3$ of its oil needs, and pays world prices for both imported oil and indirectly for its domestic oil. If CNOOC took over Unocal and only sold its output to China . . . that would replace other oil or gas that China would have bought on the world market at world determined prices .... So the oil and gas that would have been purchased by China would become available for American use at effectively the same prices Americans now pay when Unocal is an American company. ${ }^{11}$

103. Jeff French, A Concocted China Syndrome; Cnooc Failure Illustrates Need for China Inc. to Alter Its Approach, INVESTOR DEALERS DiG., Aug. 8, 2005, at 1.

104. Edward M. Graham, Op-Ed., No Reason to Block the Deal, FAR E. ECON. REv., July 2005, available at http://www.iie.com/publications/opeds/oped.cfm?ResearchID $=535$.

105. Is CNOOC's Bid for Unocal a Threat to America?, Nov. 21, 2005, http://knowledge.wharton.upenn.edu/article/1240.cfm.

106. Paul Blustein, Many Oil Experts Unconcerned Over China Unocal Bid, WASH. Post, July 1,2005 , at D1.

107. Id.

108. Id.

109. James V. Feinerman, Seven Questions: China and Unocal, ForeIGN POL'Y, July 2005, http://www.foreignpolicy.com/story/cms.php?story_id=3121.

110. Blustein, supra note 106.

111. Becker, supra note 102. 
China has only recently begun to decentralize its economy in its move away from completely state-owned businesses, and thus, does not yet fully advocate the free trade stance taken by the United States. ${ }^{112}$ Instead, it restricts U.S. investments in sectors like energy by requiring that foreign firms form joint ventures with Chinese companies and be limited to a minority share of equity ownership. ${ }^{113}$ Put simply, a U.S. corporation or the U.S. government would be forbidden from purchasing CNOOC under Chinese law. ${ }^{114}$ Some members of Congress perceive this situation as an unfair "one-way street" in which China can shield foreign countries from its own strategic industries while simultaneously tapping into those of other countries. ${ }^{115}$ Thus, members of Congress cited lack of legal reciprocity as a reason to block the CNOOC takeover on both equitable and national security grounds. ${ }^{116}$

Although Chinese law limits foreign investment in China in some circumstances, it is not completely foreclosed. 117 "Over the past two decades, China's economy has been relatively open to many types of foreign investment, and it continues to improve its investment climate" due in part to commitments it made when joining the World Trade Organization. ${ }^{118}$ The United States is the second largest investor in China, behind Hong Kong, accounting for $8.5 \%$ of foreign direct investment in the country. ${ }^{119}$ In 2004, American companies invested $\$ 60$ billion into China compared to only $\$ 2$ billion of direct investment by China into the United States. ${ }^{120}$ Both General Motors and Ford have major operations on China's mainland, Anheuser-Busch was allowed to purchase the large Chinese beermaker Harbin Brewery, and Bank of America was able to purchase a $10 \%$ stake in China's largest mortgage lender. ${ }^{121}$ Although it is undisputed that China does not yet advocate the open-door investment approach of the United States, it seems inaccurate to describe the economic relationship between China and the United States as a "one-way street," at least in relation

112. Morrison, supra note 50, at 2. Interestingly, the United States limits or prohibits foreign direct investment in such industries as maritime, banking, power, and aircraft. Jackson, supra note 14, at 5 . For example, federal law "limits foreign investment in U.S. airlines to $25 \%$ of the voting stock and limits foreign investors' ability to elect members of boards of directors and other key officers." Hon. David M. Walker, Comptroller General, Keynote Address at the International Aviation Club of Washington, State of the U.S. Commercial Airline Industry and Possible Issues for Congressional Consideration (Nov. 28, 2001), available at http://www.gao.gov/cghome/iac1 128.htm.

113. D'Amato, supra note 59.

114. Id.

115. Implementation of the Exon-Florio Amendment and the Committee on Foreign Investment in the United States: Before the Senate, Banking, Housing and Urban Affairs Committee, 109th Cong. (2005) (paraphrasing statement of Sen. Chuck Schumer).

116. Id.

117. Id.

118. NANTO ET AL., supra note 51 , at 8.

119. Morrison, supra note 50 , at 4.

120. Tyson, supra note 45.

121. Editorial, Unocal Won't Be the Last, So Set the Rules Now, Bus. WK. ONLINE, July 11, 2005, http://www.businessweek.com/magazine/content/05_28/b3942130.htm. 
to investment as a whole.

Members of Congress may have missed an important opportunity to pressure China to adopt a more open-door stance with respect to its oil policies by instead focusing on non-existent national security concerns of the merger. ${ }^{122}$ Congress could have taken the approach of welcoming the CNOOC offer and used the bid as leverage to press China for assurances of future U.S. investment opportunities in that country. ${ }^{123}$ Instead, Washington's effective blockade of the merger may have had the opposite effect: causing the United States to lose leverage in its effort to achieve greater openness with China and potentially hindering an attempted takeover of a Chinese firm by an American firm in the future. $^{124}$

The Exon-Florio provision was passed in large part because of concerns about expansive purchases by Japanese firms of U.S. businesses in the 1980s. ${ }^{125}$ During that decade, Japanese firms purchased, or at least attempted to purchase, several large American businesses, including well-known New York buildings, Hollywood movie studios, and a large U.S. semi-conductor business. ${ }^{126}$ Critics accused Japan of financing the purchase of real estate in the United States, allowing Japanese firms to pay prices that exceeded what U.S. companies could afford to pay. ${ }^{127}$ Dire predictions of the fate of the United States were made in part because Japan had a large trade surplus with the United States and chose to invest their significant foreign currency reserve in the United States. ${ }^{128}$ Concerned American politicians used rhetoric to create an irrational fear among the American public that Japan would slowly take over the United States through acquisition of its assets. ${ }^{129}$ In the end, Japanese businessmen lost a great deal of money by paying inflated prices for American real estate, ${ }^{130}$ and U.S. companies were able to buy back many of the assets at a fraction of the price. ${ }^{131}$

Due to a series of bids by Chinese businesses to acquire major U.S. companies, such as IBM, Maytag, and Unocal, comparisons have been drawn between China's current corporate shopping spree and that of Japan in the 1980s. ${ }^{132}$ In fact, just days before CNOOC announced its bid to purchase

\footnotetext{
122. James McGregor, Advantage, China in This Match, They Play Us Better Than We Play Them, WASH. POST, July 31, 2005, available at http://www.harrywalker.com/articles/archive/McGregor_WashPost_ChinaOpPiece.pdf.

123. Id.

124. Graham, supra note 104.

125. Jackson, supra 14, at 2.

126. Sebastian Mallaby, China's Latest 'Threat,' WASH. Posr, June 27, 2005, at A15.

127. Maurice Greenberg, American Posturing on China Is Short-Sighted, FIN. TIMES, July 18,2005 , at 15 .

128. Marchick, supra note 6 , at 10.

129. Ferber, supra note 1, at 810.

130. Mallaby, supra note 126.

131. Greenberg, supra note 127.

132. Unocal Bid Hits Sore Spots in U.S., INDEP., June 26, 2005, http://www.independentbangladesh.com/news/jun/27/27062005bs.htm\#A15.
} 
Unocal, former Federal Reserve Chairman Alan Greenspan and Treasury Secretary John Snow appeared before a Senate committee to discuss free trade policy with China and compared China's recent U.S. investment with that of Japan's in the 1980s. ${ }^{133}$

Many, however, believe that the Chinese takeover movement generally and CNOOC's offer to purchase Unocal more specifically cannot fairly be compared to Japanese acquisitions in the 1980s. ${ }^{134}$ Some have argued that CNOOC's bid is more favorable to protectionist reaction because China, unlike Japan, is not a major competitor of valuable resources like oil; because CNOOC is a state-run company, whereas Japan is a democratic country; because Japan was a military ally and China is not; and because oil, unlike real estate, is a strategic asset that has much greater implications for national security. ${ }^{135}$ Still, others believe these arguments are merely weak attempts to mask the fact that paranoia and distrust of China fueled congressional reaction to the CNOOC bid much more than any realistic national security concerns. ${ }^{136}$

\section{PROPOSALS FOR REFORMING EXON-FLORIO AND CFIUS}

\section{A. The GAO Report}

CNOOC's bid for Unocal raised widespread concerns among members of Congress that the current state of Exon-Florio did not adequately protect the United States from foreign acquisition of sensitive U.S. assets. ${ }^{137}$ At the request of Indiana Senator Evan Bayh, Oklahoma Senator Richard Shelby, and Maryland Senator Paul Sarbanes, ${ }^{138}$ the GAO conducted a study of the effectiveness of CFIUS's review process and released the report in September of 2005 . $^{139}$

The GAO report found that CFIUS's implementation of Exon-Florio limits its effectiveness in two primary ways. First, the Treasury, as Chair, too narrowly defines what constitutes a threat to national security. ${ }^{140}$ Secondly, CFIUS is reluctant to initiate a forty-five day investigation because of potential

133. Diane M. Grassi, China's Bid for Unocal: More Than Meets the Eye, AM. CHRON., July 19, 2005, http://www.americanchronicle.com/articles/viewArticle.asp?articleID=1237.

134. See Irwin M. Stelzer, China and Unocal: Remember When the Japanese Bought Rockefeller Center?, WKLY. STANDARD, June 27, 2005.

135. Id.

136. See Dom, supra note 8.

137. Corr, supra note 7.

138. Press Release, U.S. Senator Evan Bayh, Bayh Calls for Increased Oversight of Foreign Takeovers With National Security Concerns, (Oct. 6, 2005), http://bayh.senate.gov/releases/2005/10/060CT05PR.htm. The report was initially requested in 2003 after CFIUS approved the takeover by a Chinese company of an Indiana company that made $85 \%$ of the magnets used to guide U.S. smart bombs. Id.

139. GAO, supra note 12 .

140. Id. at 11 . 
negative impacts on foreign investment and its conflict with U.S. open investment policy. ${ }^{141}$

With regard to the first issue, the GAO report found that the Treasury did not adequately take into account the broad range of factors listed in ExonFlorio, but instead limited the definition of national security to "exportcontrolled technologies or items, classified contracts, and critical technology; or specific derogatory intelligence on the foreign company." 142 The report stated that this definition "is not sufficiently flexible to provide for safeguards in areas such as protection of critical infrastructure, security of defense supply, and preservation of technological superiority in the defense arena." ${ }^{143}$ By contrast, the study concluded that the Departments of Justice, Defense, and Homeland Security take a broader view of national security, including viewing the transaction "in terms of the potential vulnerabilities posed by the acquisition." 144 These additional factors included foreign control of critical infrastructure and control of critical inputs to defense systems. ${ }^{145}$

The GAO report concluded that CFIUS limits the effectiveness of ExonFlorio by being far too reluctant to initiate forty-five day investigations in an effort not to chill foreign investment in the United States. ${ }^{146}$ It pointed to the fact that from 1997 through 2004, CFIUS received 470 notifications but initiated only eight investigations during that period. ${ }^{147}$ The report stated that, consistent with its desire to avoid investigations, the Treasury Department applies the strict criterion that there must be "credible evidence that the foreign controlling interest may take action to threaten the national security" before an investigation is undertaken. ${ }^{148}$ Additionally, the Treasury Department must determine that "no other laws are appropriate or adequate to protect national security."149

These criteria are the same as those provided in the Exon-Florio statute as a basis for the President's decision to suspend or prohibit a foreign acquisition. But, according to the GAO report, it may not be the appropriate criteria in determining whether to initiate an investigation. ${ }^{150}$ Presently, the only guidance that Exon-Florio provides for CFIUS in determining whether to initiate an investigation is the broad language that it "may make an investigation to determine the effects on national security."

The GAO study expressed concern that the initial thirty day review

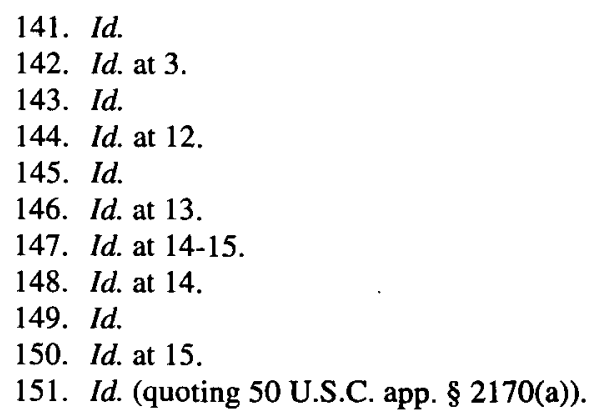


period, following notification, in which CFIUS's members must decide whether a full investigation is warranted, is not sufficiently long to gather all necessary information or to negotiate an agreement to mitigate national security concerns. $^{152}$ Instead, according to the report, to give itself additional time to make a determination, CFIUS must sometimes ask the company to withdraw their notification under threat of investigation. ${ }^{153}$ After withdrawal, problems in CFIUS's monitoring may occur when the acquisition has already been concluded because the foreign company then has less of an incentive to resolve security issues and refile in a timely manner. ${ }^{154}$

The GAO report offered a number of recommendations consistent with its findings for change in Exon-Florio. After determining that the Treasury's narrow definition of national security failed to adequately consider factors that were currently embodied in Exon-Florio and that there existed differing views within CFIUS about the extent of authority under Exon-Florio, it recommended that Congress amend Exon-Florio "by more clearly emphasizing the factors that should be considered in determining potential harm to national security."155 The report also concluded that time constraints and CFIUS's reluctance to initiate investigations allows companies to withdraw their notifications and, subsequently, CFIUS may lose track of the transaction when companies do not refile. $^{156}$

Thus, the GAO report recommended that Congress require the Secretary of the Treasury to "establish interim protections where specific concerns have been raised," to allot specific time frames for refiling, and to create "a process for tracking any actions being taken during the withdrawal period."157 The report also suggested easing time constraints by eliminating the distinction between a review period and an investigation, thereby making the entire seventy-five day period available for review. ${ }^{158}$ Lastly, the report suggested that Congress require CFIUS to make periodic reports "to provide more transparency and facilitate congressional oversight." 159

The Treasury Department disputes a number of the GAO's conclusions in its September 2005 report and insists that the current structure and policies of CFIUS have implemented Exon-Florio in a manner effective to protect national security. ${ }^{160}$ The Treasury Department stated that any agency could bring forward national security concerns for CFIUS to review and that, contrary to what the GAO study indicated, no agency "defines" national security for

152. Id.

153. Id.

154. Id. at 16.

155. Id. at 21 .

156. Id. at 20.

157. Id. at 21 .

158. Id.

159. Id.

160. Id. at 27 . 
CFIUS. ${ }^{161}$ The Treasury claimed that CFIUS considers an extremely broad range of factors in determining what constitutes a threat to national security and refuted the GAO claim that any one narrow definition was used. ${ }^{162}$ It further stated that while CFIUS is chaired by the Secretary of Treasury, it is an interagency committee and thus "[a]ll CFIUS decisions are reached only by a consensus among the CFIUS member agencies."163 It explained that disagreement between differing agencies on what constitutes a threat to national security is the product of vigorous debate when CFIUS considers a foreign acquisition and is not a fundamental defect in the committee's review process. ${ }^{164}$

With respect to its allegedly overly restrictive standard for initiating an investigation, the Treasury noted that its guidelines provide that a forty-five day investigation is undertaken if any agency has national security concerns regarding the transaction. ${ }^{165}$ The Treasury also stated its belief that the thirty day review period, although "tight," results in "foreign investments being structured to avoid national security problems" and provides incentives for those foreign companies to undergo extensive preparation before they even file notification with the Committee. ${ }^{166}$ It refuted the GAO's assertion that it encouraged companies to withdraw their notifications, noting that CFIUS guidelines give parties, and not CFIUS agencies, authority to request a withdrawal for legitimate reasons only. ${ }^{167}$

The Treasury stated its position that nearly all the concluding recommendations in the GAO report were unnecessary or counterproductive. It found no need to more clearly emphasize the factors in considering a potential threat to national security, insisting that the current framework provided by Exon-Florio gives CFIUS "the broadest possible latitude" in determining whether a foreign acquisition poses national security concerns. ${ }^{168}$ It also insisted that CFIUS has and will continue to consider as a factor "transactions involving critical infrastructure, including the "control of or access to information traveling on networks'" in determining national security threats. ${ }^{169}$ Furthermore, it disfavored the GAO's suggestion to eliminate distinctions between review and investigation periods, stating that "CFIUS completes the vast majority of its reviews within the initial thirty day review." 170 Thus, for most transactions, extending the review period to seventy-five days would unnecessarily delay the closing of the acquisition, thereby negatively affecting

161. Id.

162. Id. at 30 .

163. Id. at 27.

164. Id.

165. Id. at 31 .

166. Id.

167. Id. at 34 .

168. Id at 35-36.

169. Id. at 36 (quoting September 2002 GAO Report \#02-736).

170. Id. 
foreign investment in the United States and deterring CFIUS filings in the first place. $^{171}$

With regard to the suggestion that the Treasury increase its reporting procedures to Congress, the Treasury stressed the importance of Exon-Florio's confidentiality provision. ${ }^{172}$ The Treasury insisted that protecting the proprietary information of foreign investors from being made public is essential to encourage notification and full disclosure by foreign investors to the committee and to prevent reductions of foreign investment in the United States. ${ }^{173}$ Although the Treasury stated that closed session oral briefings to duly authorized committees of Congress was the most appropriate mechanism for reporting, it agreed to work with Congress on developing periodic reporting schedules for completed reviews to some members of Congress. ${ }^{174}$ Lastly, the Treasury stated that any measure imposing interim requirements after withdrawal "would be difficult to negotiate and would detract from efforts to complete the CFIUS review."

\section{B. Legislative Proposals}

Following the release of the September 2005 GAO report, hearings of the Senate Committee on Banking, Housing and Urban Affairs were held to discuss possible changes to CFIUS. ${ }^{176}$ Led by Senator Shelby, Chairman, and Senator James M. Inhofe, several legislative proposals have been introduced and are currently under consideration. ${ }^{177}$ Senator Shelby proposed an amendment to a defense bill that would give Congress the power to reject a foreign acquisition for national security reasons, even in cases where the President had not suspended or prohibited the deal. ${ }^{178}$ Other proposals include "[p]roviding Congress with power to veto CFIUS clearance on any proposed deal"; "[b]roadening the definition of "national security" to include critical infrastructure, economic security, and energy needs"; "[r]equiring CFIUS to report to Congress on each deal for which notification is provided"; extending the period of time for the CFIUS review process; "[1]imiting the ability of companies to avoid investigations by withdrawing notifications that are to be subsequently re-filed"; and switching the chair of CFIUS to the Department of Defense, Homeland Security, or Commerce. ${ }^{179}$ Other less drastic suggestions include requiring companies to report deals to CFIUS and giving U.S. allies

171. Id.

172. Id. at 37.

173. Id.

174. Id.

175. Id.

176. See Sen. Richard Shelby, Foreign Investment and National Security Act of 2006, S. Rep. No. 109-264, at 3 (2d Sess. 2006).

177. Corr, supra note 7.

178. Kirchgaessner, supra note 23.

179. Corr, supra note 7. 
preferential treatment as compared to more hostile countries. ${ }^{180}$

In September 2005, Senator Inhofe introduced Bill 1797, which called for a number of specific changes in Exon-Florio. ${ }^{181}$ The proposed bill would add to the list of factors in determining threats to national security U.S. requirements for sources of energy and economic security; authorize Congress to pass a joint resolution prohibiting an acquisition within ten days after the President informs Congress of his decision not to suspend or prohibit the acquisition; increase CFIUS's review period from thirty to sixty days; require that the findings and recommendations of an investigation be sent to Congress as well as the President; allow a member of the Committee on Banking, Housing and Urban Affairs to require CFIUS to undertake an investigation; and require that the Secretary of the Treasury submit quarterly submissions to the Committee on Banking, Housing and Urban Affairs containing a detailed summary of each merger, acquisition, or takeover that was reviewed or will be reviewed in the next quarter. ${ }^{182}$

The Bush Administration opposed Senator Inhofe's proposal or any other proposed changes in Exon-Florio, stating that the review process works well as currently implemented. $^{183}$ In addition, eleven major U.S. business organizations voiced their support for the Bush administration's position at recent congressional hearings. ${ }^{184}$

Little became of legislation proposing to amend Exon-Florio in the months following the withdrawal of CNOOC's bid to acquire Unocal. ${ }^{185}$ Recently, however, arguments in support of reform have been revitalized by Dubai Port World's (DP World) attempt to acquire management control of six major U.S. seaports. ${ }^{186}$ DP World is a company owned by the government of Dubai in the United Arab Emirates. ${ }^{187}$ In February 2006, DP World won the bidding war for the British firm Peninsular and Oriental Stream Navigation Company (P\&O), which controlled the right to manage U.S. seaports in New York, New Jersey, Philadelphia, Baltimore, Miami, and New Orleans. ${ }^{188}$ DP World had previously submitted a voluntary notification of its plans to acquire P\&O to CFIUS and, after a thirty-day review period, CFIUS approved the

180. Kirchgaessner, supra note 23.

181. See S. 1797, 109th Cong. (2005). This bill was referred to the Committee on Banking, Housing and Urban Affairs for consideration. Id.

182. Id.

183. Richard S. Dunham, Keeping America Safe - From Foreign Buyouts, Bus.WK. ONLINE, Oct. 24, 2005, http://www.businessweek.com/magazine/content/05_43/c3956074.htm.

184. Id.

185. See Ronald D. Lee \& Nancy L. Perkins, Securing U.S. Strategic Assets: Does the Exon-Florio Statute Do Its Job?, CHINA TRADE L. REP. (Apr. 2006), noting the failed efforts of Senators Inhofe and Shelby to have their proposals for reform included in the National Defense Authorization Act of Fiscal Year 2006.

186. Id.

187. Key Questions About the Dubai Port Deal, CNN.CoM, Mar. 6, 2006, http://www.cnn.com/2006/POLITICS/03/06/dubai.ports.qa/index.html.

188. Id. 
acquisition in January 2006. ${ }^{189}$ As part of the approval, DP World made concessions to CFIUS by agreeing to open its books and keep the current U.S. ports management intact. ${ }^{190}$

In February 2006, the Dubai Port deal became highly politicized when critics of the takeover raised national security concerns. ${ }^{191}$ Critics noted that two of the September 11 hijackers came from the United Arab Emigrates and the hijackers drew funds from bank accounts in Dubai. ${ }^{192}$ A bipartisan group of lawmakers, including Senate Majority Leader Bill Frist, threatened to introduce legislation designed to delay or block the transaction. ${ }^{193}$ President Bush responded to this criticism by adamantly defending the deal, stating he would veto any bill designed to hold up the agreement. ${ }^{194}$ Facing fervent opposition from lawmakers, DP World agreed to delay the acquisition and submit to a forty-five day investigation by CFIUS in an effort to alleviate congressional concern that the takeover posed a national security threat. ${ }^{195}$

DP World's willingness to undergo a full CFIUS investigation did not, however, discourage members of Congress from taking measures to prevent the deal in the interim. On March 8, 2006, the House Appropriations Committee voted sixty-two to two to block the agreement to allow DP World to operate U.S. seaports. ${ }^{196}$ One day later, House and Senate GOP leaders bluntly informed President Bush that Congress would prevent the agreement from being implemented. ${ }^{197}$ DP World ultimately succumbed to the political pressure and announced that it would sell its U.S. operations to an American company. ${ }^{198}$

In the wake of the Dubai Port deal controversy, lawmakers have a renewed desire to reform the investment review process and are once again proposing legislation designed to accomplish this goal. ${ }^{199}$ On March 7, 2006, Senator Dodd introduced legislation that would add the director of National Intelligence and the CIA Director to CFIUS; create an intelligence subcommittee to review all potential deals; require congressional notification at every step of the CFIUS process; and make notification to the President or CFIUS mandatory. ${ }^{200}$ Senators Inhofe and Shelby have also renewed their

189. Id.

190. Id.

191. Bush, Congress Clash over Port Sale, CNN.com, Feb. 22, 2006, http://www.cnn.com/2006/POLITICS/02/21/port.security/.

192. Id.

193. Id.

194. Id.

195. Ports Buyer Requests 45-Day Review of Deal, CNN.COM, Feb. 26, 2006, http://www.cnn.com/2006/POLITICS/02/26/ports.dubai/.

196. Congress Declares War on Ports Deal, CNN.COM, Mar. 8, 2006, http://www.cnn.com/2006/POLITICS/03/08/port.security/index.html.

197. Dubai Firm to Sell U.S. Port Operations, WASH. POST, Mar. 10, 2006, at A01.

198. Id.

199. Lee \& Perkins, supra note 185.

200. S. 2380 109th Cong. (2006). 
efforts to pass legislation reforming CFIUS. ${ }^{201}$

\section{A CRITICAL REVIEW OF PROPOSALS FOR REFORM IN EXON-FLORIO AND CFIUS}

\section{A. Defining and Expanding the Definition of "National Security"}

Recent suggestions to expand the definition of "national security" to include domestic economic concerns are not novel proposals; they have been suggested frequently since Exon-Florio was adopted. ${ }^{202}$ Just as past suggestions for expansion of the definition have not been implemented, it is currently unwise and unnecessary to do so. Criticisms leveled against ExonFlorio have often involved what many consider its vague definition of "national security."203 It has been argued that a failure to create clear standards for what constitutes a threat to national security creates uncertainty among foreign investors when structuring acquisitions of U.S. companies and in turn decreases foreign direct investment in the United States. ${ }^{204}$ In addition, this vagueness may create unnecessary transactional delays, since foreign firms that would not be considered a national security threat feel pressure to report their investments to CFIUS. ${ }^{205}$

Concerns of this type have led to suggestions, which were ultimately rejected, that CFIUS should annunciate a list of products and services it considers essential to national security or create a list of industries exempt from Exon-Florio. $^{206}$ Given these concerns, one can expect that implementing a statutory requirement that CFIUS consider potential threats to "economic security" in determining a threat would only add to the confusion. ${ }^{207}$ The term "economic security" is an extraordinarily vague one, creating a level of uncertainty that could potentially hinder foreign investment in the United States and a means for protectionist-minded politicians to argue for the prohibition of beneficial corporate transactions. ${ }^{208}$

201. Press Release, Senator Inhofe, Recent Port Deal Further Reveals Need for CFIUS Reform (Feb. 21, 2006), available at http:Inhofe.senate.gov/pressapp/record.cfm?id=253411. See, Senator Shelby, supra note 176; see also, S. 3549 109th Cong. (2006).

202. Marchick, supra note 6 , at 8.

203. See W. Robert Shearer, The Exon-Florio Amendment: Protectionist Legislation Susceptible to Abuse, 30 Hous. L. REv. 1729, 1768 (1993) (arguing that the vague meaning of "national security" gives the President and CFIUS too much discretion to control foreign investment in the United States, creates uncertainty among foreign investors, and allows for threatening foreign acquisitions to escape CFIUS's attention). Id.

204. Id.

205. Ferber, supra note 1 , at 827.

206. Shearer, supra note 203 , at 1741 .

207. Marchick, supra note 6 , at 8.

208. See id. (quoting the statement of former Commerce Secretary Malcolm Baldridge, 
By contrast, others have argued that the only way to prevent protectionist abuse and maximize beneficial foreign investment is to limit the definition of a threat to national security to "only those transactions that closely bear on national defense."209 Prior to September 11, 2001, CFIUS took this more narrow approach, focusing "primarily on the protection of the U.S. defense industrial base, the integrity of Department of Justice investigations, and the export of controlled technologies., 210

In the wake of the terror attacks on the United States and the subsequent war on terrorism, however, the Departments of Justice and Defense, as agency members of CFIUS, now take a broader view of what might constitute a threat to national security by considering vulnerabilities that may result from foreign control of critical infrastructure. ${ }^{211}$ Despite the fact that the Treasury Department may continue to take a narrower, more traditional view of what constitutes a threat to national security, the fact that all decisions by CFIUS are based on the consensus vote of all agencies should alleviate concerns that one overly narrow or overly broad definition is used. ${ }^{212}$ Thus, keeping "national security" undefined will ensure that national security is adequately protected without increasing the present ambiguity in the meaning of the term.

\section{B. Expanding Congressional Authority}

Congressional reaction to CNOOC's bid demonstrates " $[\mathrm{t}] \mathrm{he}$ increasingly confrontational approach Congress is taking toward China."213 As discussed above, the relatively trivial assets of Unocal, the fungible nature of oil, and CNOOC's contractual concessions reveal that Congress' reaction to the bid was both irrational and unsupported by the facts. ${ }^{214}$ It is precisely because of the strong potential that members of Congress will enact harmful protectionist measures based on anti-China perspectives that proposals to allow Congress to prohibit foreign acquisitions after the President has approved them should not be implemented. As both the CNOOC and Dubai Port transactions demonstrate, through politicization Congress already has the ability to intimidate foreign investors, thereby raising the cost of transactions or effectively preventing them from occurring. ${ }^{215}$ Statutory authority to prohibit a deal would encourage protectionist measures to be enacted whenever a Chinese company seeks to purchase an American one, which in turn would create a

\footnotetext{
"you are trying to kill a gnat with a blunderbuss," to support the proposition that an "economic security" test would serve as a vehicle for domestic industries to block foreign competition). Id.

209. Robert N. Cappucci, Amending the Treatment of Defense Production Enterprises Under the U.S. Exon-Florio Provision: A Move Toward Protectionism or Globalism?, 16 FORDHAM INT'L L.J. 652, 680 (1993).

210. Marchick, supra note 6, at 4.

211. GAO, supra note 12 , at 12 .

212. Id. at 30.

213. Dorn, supra note 8 , at 1 .

214. See also id. (arguing that any threat to U.S. national security posed by the CNOOCUnocal case was remote at best).

215. Id. at 6.
} 
number of direct and indirect problems.

To begin with, allowing Congress to prohibit acquisitions previously approved by the President would create a great deal of uncertainty among foreign investors regarding "the prospect of congressional involvement in the review process."216 This could lead to decreased foreign investment in the United States. ${ }^{217}$ After all, if currently proposed legislation is enacted, a foreign acquirer could potentially be forced to wait the full seventy-five days for CFIUS to complete its review and investigation, gain presidential approval, and then see the deal quashed by a joint resolution of Congress. Congress' role should be limited to ensuring that Exon-Florio is properly implemented, but it should not itself act as a regulatory agency. ${ }^{218}$ Considering the animosity toward China and congressional ignorance about energy markets, as demonstrated by CNOOC's bid, this is essential to ensure that beneficial foreign investment in the United States is not discouraged. ${ }^{219}$

Secondly, if U.S. politicians continue to politicize bids by Chinese companies, it is likely that the Chinese government may retaliate by using spurious reasons to block attempts by U.S. firms to acquire Chinese companies. ${ }^{220}$ At the very least, congressional involvement in these corporate transactions could only harm the United States' effort to achieve greater openness to invest in the Chinese market; a market that has become increasingly open to foreign investment over recent years. ${ }^{221}$ This is especially the case given that other non-Chinese foreign companies, such as British Petroleum and Royal Dutch Petroleum, are free to invest in U.S. energy assets. ${ }^{222}$ This inequitable treatment is unlikely to be perceived kindly by the Chinese government and could lead to a decline in permissible U.S. investment in China.

It is entirely plausible that the ability of Congress to thwart the CNOOC bid may have actually decreased the security of the United States. This can be seen when one considers where China has turned to obtain the necessary oil to fuel its economy. Recently, China has secured oil acreage in countries like Iran, Sudan, and Venezuela. ${ }^{223}$ In fact, China recently became Iran's biggest oil and gas customer, signing long-term contracts worth around $\$ 200$ billion. ${ }^{224}$ China's need to increase its dealings with countries like Iran in order to fulfill its energy needs has the potential to undermine the United States' efforts to isolate these countries and may aggravate tension between the United States

216. Marchick, supra note 6 , at 8 .

217. Id.

218. Id.

219. Dorn, supra note 8, at 7 .

220. Graham, supra note 104.

221. Id.

222. Dorn, supra note 8, at 4.

223. Amy Myers Jaffe, Wasted Energy, N.Y. Times, Jul. 27, 2005, at A23.

224. Antoaneta Bezlova, Seeking Oil In Troubled Waters, IPS-INTER PREss SERvice, Sept.

19, 2005, available at http://www.speroforum.com/site/print.asp?idarticle=1921. 
and China. ${ }^{225}$ This is yet another reason why increased congressional involvement and subsequent politicization of foreign corporate transactions is unwise.

The Dubai Port deal further demonstrates that politics surrounding a transaction can strongly influence how it is structured and whether or not it is ultimately completed. ${ }^{226}$ Amendments that propose to allow Congress to block transactions to which CFIUS does not object or veto CFIUS's clearance to review a proposed deal will only further inject politics into commercial transactions and discourage beneficial foreign investment. ${ }^{227}$

Thus, lessons from the failed CNOOC-Unocal merger and the Dubai Port deal weigh strongly against enacting proposals that increase congressional authority over the regulation of foreign investments.

\section{Extending the CFIUS Review Process}

Proposals have been suggested that would extend CFIUS's review period from thirty to sixty days or even eliminate the distinction between a review and an investigation completely, making the entire seventy-five days a reviewable period. ${ }^{228}$ Some have argued that extending the time frame for a CFIUS review is unnecessary because most companies file only after engaging in informal conversations with CFIUS. $^{229}$ These informal consultations give CFIUS "additional time to assess national security risks and design mitigation strategies" and sometimes result in security agreements being completed before parties even file. ${ }^{230}$ In addition, in a majority of cases, the thirty day review period is sufficiently long for CFIUS agencies to adequately access whether they should undertake an investigation. ${ }^{231}$

But, good reasons exist for extending the CFIUS review process, at least under some conditions. In response to the September 2005 GAO report, the U.S. Department of Justice, an agency of CFIUS, said:

The Department shares the concern expressed in the draft report with respect to time constraints imposed by the time limits of the current process. In particular, gathering timely and fully-vetted input from the intelligence community is

225. Jaffe, supra note 223.

226. Lee \& Perkins, supra note 185 .

227. Id.

228. See S. 1797, 109th Cong. (2005); see also GAO, supra note 12, at 21 (suggesting eliminating the distinction between a review and an investigation and making the entire seventyfive day period available for review to address the Treasury's concern with the impact of investigations on U.S. open investment policy and to address member agencies' concerns about needing more time during initial reviews).

229. Marchick, supra note 6, at 9.

230. Id.

231. GAO, supra note 12 , at 31 . 
critical to a thorough and comprehensive national security assessment. Any potential extension of the time available to the participants for the collection and analysis of that information would be helpful. ${ }^{232}$

Likewise, even though the Treasury Department believes that for most transactions extending the review by forty-five days would be unnecessary and detrimental, it concedes that "for certain transactions an extension of time available for the collection and analysis of information would ease the burden on the government." ${ }^{\text {"33 }}$ The GAO report also claims that in some cases where agencies need more time to gather information, the Committee suggests that companies withdraw their notification and refile at a later time. ${ }^{234}$ In some instances, companies have delayed refiling or have not done so at all after their withdrawal. ${ }^{235}$

The solution to this issue appears to lie in determining the length of time in which the agencies of CFIUS can complete a thorough review without unreasonably delaying the closing of an acquisition and deterring CFIUS filings in the first place. One solution might be for Congress to amend Exon-Florio in a manner that would continue to use the thirty day review period, but provide CFIUS with an option to extend the review period by fifteen, or even thirty days at its discretion. This would prevent unnecessary delays in the vast majority of cases where CFIUS can complete a comprehensive review within thirty days, but would allow agencies the additional time they need to complete a thorough review in rare circumstances.

\section{Switching the Chair of CFIUS}

Over the years there have been a number of proposals that would switch the chairmanship of CFIUS from the Treasury Department to another agency, such as the Department of Defense or the Department of Commerce. ${ }^{236}$ Such proposals stem from criticism that the Treasury's primary goal of reducing the deficit, which is furthered by allowing foreign investment, is inconsistent with Exon-Florio's primary goal of protecting national security through monitoring and regulating foreign investment. ${ }^{237}$ Thus, it is argued that the Treasury's main focus creates a bias against CFIUS activity. ${ }^{238}$ The GAO report supports this criticism, by citing examples of transactions where the narrower definition of national security prevailed when agencies differed about whether the case

232. Id. at 48 .

233. Id. at 36 .

234. Id. at 15.

235. Id. at 15-16.

236. Marchick, supra note 6 , at 9.

237. See Cappucci, supra note 209, at 678 .

238. Id. 
constituted a national security threat. ${ }^{239}$ The Treasury Department countered by claiming that only "CFIUS, as a Committee, decides whether there are threats to the national security.",240

Since all CFIUS decisions are made on a consensus basis, it is unlikely that the Treasury Department's allegedly narrow definition of what constitutes a threat to national security predominates. ${ }^{241}$ This is especially the case given that CFIUS Guidelines state that "[i]f any agency has national security concerns regarding ... [a] transaction," a forty-five day investigation is undertaken. ${ }^{242}$ Thus, where CFIUS chooses not to undertake a forty-five day investigation of a transaction, it is only because no CFIUS agency, not just the Treasury Department, deemed it necessary to do so.

Further, even if those critical of the Treasury Department's chairmanship are correct in claiming it too narrowly defines national security and that this position often prevails in CFIUS's decisions as a whole, the Treasury should continue to chair CFIUS. The reason is simple. As the failed CNOOC-Unocal merger and Dubai Port deal illustrate, if CFIUS is in fact too lenient in regulating foreign investment, congressional politicization of high-profile mergers more than makes up for this deficiency. Thus, in order to maintain a proper balance between free trade and protectionism, CFIUS should continue to be chaired by an agency that advocates an open investment policy. In addition, maintaining chairmanship in the Treasury sends a positive message to potential foreign investors that the United States presumptively welcomes foreign investment; a message that is less clear if CFIUS were chaired by a department with a focus on national defense. ${ }^{243}$

Others have suggested that CFIUS be reorganized as a more independent agency. ${ }^{244}$ Under this system, new members would "function independently of other federal agencies and departments," perhaps preventing the disruptive effects of conflicting positions on issues of foreign investment that prevent CFIUS from adopting a clear national security policy. ${ }^{245}$ But while a clear definition of national security from a single independent agency may be seen as a benefit to some, it could also be seen as a weakness to others. CFIUS's multiple-agency structure arguably provides benefits by requiring compromise on what constitutes a threat to "national security" between numerous branches whose priorities and goals conflict. ${ }^{246}$ This in turn could be said to prevent any one overly narrow or exceedingly broad definition from being used. ${ }^{247}$

239. GAO, supra note 12 , at 12-13.

240. Id. at 30.

241. Id. at 4-5.

242. Id. at 31 (emphasis added).

243. Marchick, supra note 6, at 9.

244. Cecelia M. Waldeck, Note, Proposals for Limiting Foreign Investment Risk Under the Exon-Florio Amendment, 42 HASTINGS L.J. 1175, 1252 (1991).

245. Id. at 1252-53.

246. GAO, supra note 12 , at 30 .

247. Id. 


\section{E. Increasing CFIUS Reporting Requirements}

Few would dispute that Congress has a legitimate role in ensuring that CFIUS correctly implements Exon-Florio. Naturally, this requires some amount of reporting to Congress, but the appropriate amount of such reporting remains in dispute. Currently, Exon-Florio requires that the President send a written report to Congress whenever he makes a decision about whether a transaction should be prohibited. ${ }^{248}$ It also requires that agencies of CFIUS "with equities in any particular transaction, provide briefings to duly authorized committees of Congress whenever requested, following completion of action under the statute." 249

There are a number of reasons why an expansion of congressional oversight over CFIUS's review process is warranted. First, implementing more expansive reporting procedures will help to ensure that CFIUS is held accountable for its role in implementing Exon-Florio. Congress would then have information regarding the nature of certain transactions, the potential national security concerns posed by different agencies of CFIUS, and the ways in which those concerns were mitigated. ${ }^{250}$ Perhaps most importantly, by requiring CFIUS to be more accountable to Congress, proposals to amend Exon-Florio to authorize Congress to reject a foreign acquisition for national security reasons, even in cases where the President had not suspended or prohibited the deal, would be less likely to be implemented. The fact that only two cases have been reported to Congress since 1997 contributes to the opaque perception of CFIUS's review process and adds to the feeling among some members of Congress that CFIUS does not adequately protect domestic security. ${ }^{251}$ Expanding congressional oversight would eliminate many of these concerns without the need for Congress to step beyond its proper role as a supervisory, as opposed to a regulatory body, in the realm of foreign investment.

It is also important to note that CFIUS agencies do not appear to object to increased congressional oversight. The Treasury Department has stated that it is "happy to work with Congress on developing a reasonable periodic reporting schedule for completed reviews to give interested Members information about transactions." ${ }^{252}$ Likewise, the U.S. Department of Justice is not opposed to

248. GAO, supra note 12, at 20. Exon-Florio initially required the President to report to Congress only in the case of a negative decision regarding a transaction. Id. "To improve congressional oversight, the Byrd Amendment expanded required reporting to include the circumstances surrounding all presidential decisions." Id.

249. Id. at 37.

250. Id. at 21 .

251. Id. at 20.

252. Id. at 37. 
making CFIUS's review process more transparent to Congress and more susceptible to its scrutiny so long as confidential proprietary information of filing companies is protected. ${ }^{253}$ Keeping such information confidential is arguably necessary to prevent diminution in the number of applications CFIUS receives and to afford foreign investors the confidence to provide CFIUS with the full disclosure necessary to undertake a thorough review. ${ }^{254}$

The current Exon-Florio provision provides that no information or documentary material filed with CFIUS may be made public, but continues on to state that this should not "be construed to prevent disclosure to either House of Congress or to any duly authorized committee or subcommittees of the Congress."255 Therefore, the statute appears to be sufficiently broad to allow for increased congressional scrutiny without amending Exon-Florio in this regard.

\section{F. Modifying the Rules Regarding Withdrawal}

To ensure that national security is protected during the period that foreign investors withdraw their notification to CFIUS and subsequently complete their transactions with U.S.-based companies, the GAO report suggested that the Treasury "establish interim protections where specific concerns have been raised, specific time frames for refiling, and a process for tracking any actions being taken during the withdrawal period."256 The Treasury Department responded by stating that "[i]nterim measures are difficult to negotiate and would detract from efforts to complete the CFIUS review," where the emphasis should stay. ${ }^{257}$

The GAO report cited eighteen acquisitions since 1997 in which companies withdrew their notification. ${ }^{258}$ In sixteen of those cases, the acquisition had not yet been concluded and the companies refiled within four months. 259 In the other two, "the companies had already concluded the acquisition, and nine months and one year, respectively, passed before the companies refiled." 260 In yet two other cases, companies that had concluded their transaction withdrew their notifications and never refiled. ${ }^{261}$

The problem with the GAO's position is that notification is not mandatory in the first place. Thus, should CFIUS impose mandatory conditions for withdrawal where the transactions have been or will be completed during the withdrawal period, foreign investors may be inhibited or

253. Id. at 48 .

254. Id.

255. 50 U.S.C. app. $\$ 2170$ (c) (2005).

256. GAO, supra note 12 , at 21 .

257. Id. at 37.

258. Id. at 16.

259. Id.

260. Id.

261. Id. 
discouraged from making initial filings. ${ }^{262}$ This is especially the case if the GAO report is accurate in concluding that the thirty day review period is sometimes an inadequate amount of time for CFIUS to complete a review and that CFIUS subsequently has occasionally encouraged withdrawals. A voluntary notification system accompanied by mandatory conditions where such voluntary notification is withdrawn seems wholly inconsistent.

A potential solution to this inconsistency would be to make all notifications to CFIUS mandatory. ${ }^{263}$ Past proposals have called on Congress to require all U.S. companies involved in national security-related business that plan a merger or acquisition with a foreign entity to notify CFIUS of the transaction. $^{264}$ The strongest argument in favor of mandatory filings is that review of a transaction after it has been completed may mean "that national security has already been compromised." 265 Any CFIUS committee member is permitted to submit notice of a proposed or completed transaction for review when it becomes aware of a transaction and a foreign entity has failed to file with CFIUS. $^{266}$ No member agency has ever done so, however, and instead, member agencies have chosen to notify the Treasury of the acquisition so that the Treasury can contact the company and encourage it to notify. ${ }^{267}$ In addition, there have been some instances where CFIUS was completely unaware of a transaction for a substantial period of time after the acquisition was complete, prompting concerns about whether national security was compromised over this period. $^{268}$

There are, however, good reasons for opposing a mandatory filing system. ${ }^{269}$ First, it is highly uncommon for CFIUS to be unaware of a proposed or pending transaction that threatens national security because it receives a great deal of information about such transactions from government agencies that are not members of CFIUS. ${ }^{270}$ The infrequency in which CFIUS is unaware of potentially threatening foreign acquisitions must be kept in mind when weighing the potentially significant damage to the U.S.'s investment environment that a mandatory filing requirement may have. ${ }^{271}$ Such a requirement undermines the government's goal of promoting open investment,

262. Id. at 48 .

263. BurEau of EXP. AdMIN., U.S. DEP'T OF COMMERCE, IMPROVEMENTS ARE NEEDED IN Programs Designed to Protect against the Transfer of Sensitive Technologies to COUNTRIES OF CONCERN 54 (2000), available at http://www.oig.doc.gov/oig/reports/2000/BISIPE-12454-03-2000.pdf.

264. Id. at 55.

265. Id. at 54.

266. GAO, supra note 12 , at 8-9.

267. Id. at 9 .

268. See BUREAU OF EXP. ADMIN., supra note 263, at 54-55 (describing the times in which foreign entities who purchased sensitive technology did not file for an extended period of time and CFIUS's monitoring system did not discover the transaction).

269. See Robertson, supra note 32.

270. Id.

271. Id. 
a policy that helps to ensure economic growth and a higher standard of living in the United States. ${ }^{272}$ Second, mandatory filings would lead to a sharp increase in the number of filings, potentially overwhelming governmental resources and resulting in less thorough reviews. ${ }^{273}$ Lastly, the President retains the right to void any transaction that was not reviewed by CFIUS, which provides an additional incentive for foreign entities to file in the first place. ${ }^{274}$ In the end, a cost-benefit analysis of implementing mandatory filings weighs in favor of the status quo.

\section{CONCLUSION}

As discussed previously, the failed CNOOC-Unocal merger reinvigorated a protectionist fervor that has led to a number of proposals to amend CFIUS and alter the structure and procedures of CFIUS. While relatively minor procedural changes to Exon-Florio, such as an optional review extension and making CFIUS's review process more transparent to Congress, are supported by logical and beneficial justifications, most of the other proposals are not so fortunate.

Proposals to expand the definition of national security, authorize Congress to override a presidential decision, switch the chairmanship of CFIUS, and require mandatory filings and interim protections are all proposals that would alter the substantive framework of Exon-Florio and CFIUS. This would likely decrease foreign investment in the United States-investment that benefits the United States by raising labor productivity, income, and employment. ${ }^{275}$ Whether members of Congress like it or not, the United States' economic security is intertwined with China and depends upon free market policies. ${ }^{276}$ As former Federal Reserve Chairman Alan Greenspan stated, "[I]t is in our interest and that of the global economy that China continue to progress toward becoming a more market-based, productive, and dynamic economy .... For our part, it is essential that we not put that outcome, or our future, at risk with a step back into protectionism." 277

272. Id.

273. BUREAU OF EXP. ADMIN., supra note 263, at 56.

274. Robertson, supra note 32.

275. Mack Ott, Foreign Investment in the United States, CONCISE ENCYCLOPEDIA OF ECON., http://www.econlib.org/LIBRARY/Enc/ForeignInvestmentintheUnitedStates.html (last visited Dec. 12, 2006).

276. Dorn, supra note 8 , at 1 .

277. Id. at 8 . 